\title{
In a Historical Heritage Trap: Modern Social-philosophical Approach to the Problem of Transformation of Post-Soviet Society
}

\author{
Myasnikov Andrej Gennadjevich \\ Penza State University, Penza, Russia
}

\begin{abstract}
The article deals with the actual social and philosophical problems connected with the value transformations of post-Soviet society in the transition period of its development. The focus is on mental (ideological) attitudes or "traps for practical reason" that prevent the democratization and humanization of Russian public consciousness. One of such mental attitudes is the trap of historical heritage, which is a complex of probabilistic judgments about the historical purpose of society and the complete determination of the future by its past. In the course of rational-critical analysis, the erroneous biogenetic approach to Russian history is revealed, as well as possible negative consequences of its application to the solution of urgent social problems. The historical situation of the "Blockade of Leningrad" is considered to be such a pressing problem.
\end{abstract}

Keywords: historical heritage, trap for practical reason, post-Soviet society, public consciousness, Russia

Modern social philosophy systematically studies the transformation of the social consciousness of Russians in the post-Soviet period. For this purpose, structural and phenomenological methods, empirical data, and various theoretical models are used to study stable traditional stereotypes of consciousness, as well as new mental attitudes and concepts that can have a very different impact, including negative ones. Among the negative attitudes of public consciousness can be attributed the so-called "traps for the practical mind" that can mislead many of our contemporaries and thus prevent the dynamic and progressive development of the entire Russian society (Myasnikov, 2017). Special attention should be paid to the new mental attitudes associated with the historical past of our country and its modern understanding.

\section{Without What Past, There's No Future?}

The historical boom that began in post-Soviet Russia in the late 1990s gave many Russians an opportunity to think about the past of their family, their people and their state. Most of our fellow citizens have never had such an opportunity before, first of all, because of illiteracy and lack of information sources. Let us not forget that on the eve of the First World War in Russia only $2 \%$ of the population had secondary and higher education. At the beginning of the twenty-first century, these obstacles no longer exist, but new, more sophisticated

Acknowledgement: The research was carried out with the financial support of the Russian Foundation for Basic Research (RFBR) within the framework of scientific project No. 19-011-00137 "The evolution of freedom in post-Soviet society: socio-philosophical analysis and practical modeling".

Myasnikov Andrej Gennadjevich, Ph.D. in philosophy, professor of Methodology of Science, Social Theories and Technologies Department of Penza State University, Russia. 
obstacles appear, for example, in the form of mental traps, stereotypical attitudes of the mass consciousness, meme viruses, which are intended to influence the very historical knowledge and, in fact, to manipulate it. It is no secret that historical cognition in Russia has always been very mythologized and ideologized, dependent on political conjuncture. But if in the past centuries it was quite easy to manipulate mass consciousness on behalf of the supreme, absolute power and its sacral interests, then in the information, democratic era it becomes not easy.

So, let's try to deal with the statement, which is quite widespread in the modern public sphere, that "without the past, there is no future". The majority of those who repeat this idea usually want to emphasize the inseparable connection of the future with our past, and above all, the fact that the past largely determines the present and the future, determines them. Of course, there is a rational sense in this statement, but at the same time, it is quite easy to transform it and present it as a very sophisticated ideological conclusion - the future must obey the past. This conclusion is an assertion of rigid historical determinism, which can be beneficial to some politicians, officials and political scientists, as it severely limits the free self-determination and self-expression of our contemporaries.

The thesis that the future must obey the past is actively used in modern manipulative technologies, because it has a very important social and practical value: if the future must obey the past, it is possible to give different interpretations of this "past", and it will allegedly almost automatically guide us to the necessary "future" (Auzan, 2010). It will be very similar to natural determinism, which does not depend on people, on their reason and will. In this case it is as if a certain "historical, cultural genome" or something of this kind biologo-genetic, which is supposedly prescribed to us by the nature-provision-god, etc., is working. And it will be like a historical inevitability- “destiny" from which you can't escape. Thus, we find ourselves in a real worldview trap of historical heritage.

This trap is very convenient for modern manipulative technologies, and it is actively used by many official propagandists, politicians, journalists, market scientists, especially historians (for example, V. A. Nikonov, etc.) to show "great scientific character" of their historical conclusions and their determining importance for the future development of the country (Nikonov, 2015). But the philosophical, rational-critical analysis of these arguments shows their inconsistency, or, more precisely, their falsity and, moreover, their great danger for the democratic development of Russian society. After all, these attitudes form a naive-dogmatic way of thinking, close to a fatalistic mindset.

So, what is the inaccuracy of this thesis?

The idea that the past influences the present and the future is plausible, but needs to be clarified by asking: How much does it affect? To what extent? It is obvious that our past life influences the present, but not the "reinforced concrete necessity". Moreover, when it comes to the big society and its history. Nikolai Berdyaev wrote about the "Destiny of Russia" at the beginning of the 20th century and tried to understand the past as a certain interrelated sequence of events. At the same time, he did not predict any definite future for Russia, because it depends on the people themselves, on their constant choice, on their own mind and willful decisions. Attempting to prescribe today's and future human decisions and actions to the "past" is, in fact, an act of violence, or, more precisely, a cunning of power-loving "historians" who want to impose their understanding of the future in which they are interested on society. To what extent is a person's choice determined by his or her past life, for example, personal and ancestral experience, historical memory and habitual patterns of behavior? Is it possible to calculate it, to calculate it? These questions require careful consideration, rational-logical and 
empirical testing, which science has not yet reached. How strong is a person's memory to determine his present decisions and future choices? Obviously, it depends on the most concrete person, his individual abilities, including memory. For example, if we take modern youth growing in the information age, it makes no sense for them to remember a lot, because almost any information can be easily found on the mobile Internet, which is always at hand. And maybe, this technical progress for the best? The new generations will not remember too much, and will get rid of the "chains of historical heritage" more quickly. It will be important to know and remember the most essential principles on which decision-making depends.

\section{The Heirs Are Involuntary? Against the Biogenetic Approach to History}

The most popular type of the so-called "historical trap" is the statement that we are the heirs of the great, heroic, victorious past, which inexorably leads us to new grandiose achievements, great victories and world greatness (Russia in Search of Ideologies, 2016). Such a pathos tone should infect the enthusiasm, inspire new exploits, strengthen the belief in the power and the great purpose of the country.

But a sensible and sober approach to our national history shows that, in addition to the heroic and majestic, there was a lot of inhumane, criminal, mean and terrible in it, for example, the humiliating position of the majority of serfs and Soviet peasants, The Russian Orthodox Church's ideological monopoly on spiritual and moral control over the life of Russians eventually led to terrible persecution of the church. Many examples from our national history are negative examples, the most important "lessons of history" to be learned by the new generations in order not to repeat these terrible mistakes in the future. But it turns out that this sober and sensible attitude to the native history weakens the heroic pathos and makes selective, thoughtful attitude to the historical heritage itself.

What do we want to be heirs to? Noble or peasant culture? The autocratic or working peasant power? "An immortal regiment" or "immortal barracks"? It is necessary to choose, thus knowing that both were in our history: and millions of denunciations on the neighbors, dictatorship of a party, reprisals, and heroic self-sacrifice of millions Soviet people during the Great Patriotic War, and the Soviet occupation of the Baltic countries in the beginning of the Second World War, and clearing of Europe from fascism in the spring of 1945.

All of this was, and remains, our common historical heritage, which can influence our opinions, decisions and future actions. But the choice of one's historical preference is left to the individual, and it is up to the individual to learn the "lessons of history", because the individual can "forget" what he or she does not like (or benefit from) at the present time. It will be my free choice of the past that will determine the present and the future, and I will be personally responsible for that choice. Therefore, we are not at all "heirs of the will" (as some political subjects would like it to be), because each time we choose who to imitate and what to follow, and what to strive for. This choice does not happen automatically, not according to the biogenetic algorithm or to a certain "historical genome", but according to our understanding, and according to our will, i.e. freely.

That is why the future is fundamentally open and depends on us, or rather on me and you and all the others, and not on the faceless subject- "our past", on which it is convenient to write off all of our mistakes, vices, misunderstandings and crimes, justifying ourselves by the fact that "fate is such" and "nothing can change here". And in the end, nobody is to blame. Perhaps, personal and collective irresponsibility helps people survive in conditions of low degree of freedom-independence, for example, to a serfdom or a soldier, for whom someone makes decisions, and requires only obedience. In such conditions it is simply stupid to take 
responsibility: let gentlemen, chiefs, commanders think and decide, this is their concern, and our business is small...

However, in our information and prosperous time such irresponsibility seems to be a child's play and frivolous infantile, because any official and not official submission nowadays presupposes personal consent of a person to the consequences of this submission: if you don't want to, you won't obey, and you won't do someone else's will.

This also applies directly to the historical heritage: we decide for ourselves which "lessons of history" to learn, which ones to take into account in our lives, or which ones to ignore. Such subjective and selective attitude to the historical heritage may seem too free and even dangerous to some people. But it is better for adults to decide for themselves than to live by someone else's orders. Everyone has the right to remember what he or she wants and to choose for himself or herself the ideal goals that he or she considers valuable and worthy. And if someone likes another, let them live differently.

\section{Social and Practical Analysis of the Problem Situation of Leningrad Blockade}

Now we can apply the findings to an important problem situation that was updated in the Russian public space a few years ago. This situation, connected with modern assessments of the Leningrad blockade of 1941-1944, received a scandalous resonance in the winter of 2014, after a survey appeared on the website of the TV channel "Rain", in which it was proposed to vote "whether it was necessary to surrender Leningrad in order to save hundreds of thousands of lives". Soon the survey was removed by the editor-in-chief of the website and they apologized, but so far it has been on the website for about 10 minutes, $53 \%$ of those who had time to answer it believed that yes, surrender of Leningrad would have reduced the number of victims of the war.

The official position of the state on this issue was formulated by the President's spokesman Dmitry Peskov:

This is a question of absolute moral and ethic, and it is beyond what is morally and ethically acceptable for our people. $<\ldots>$ As soon as we begin to show even the slightest tolerance to such polls, we will begin the erosion of the nation, the erosion of our memory, the genetic memory of our people. I am convinced that in many countries, of course, we would have to have a much tighter channel that would cross such a moral and ethical red line ${ }^{1}$.

The indignation of some part of Russian society was largely due to the fact that the very sacral nature of this state sacrifice was questioned from the point of view of the modern humanistic system of values. According to the modern political philosopher G. Kozyrev, this kind of desacralization of state victims weakens the very value foundation of the "defense consciousness", the traditional Russian ruling model of life (Kozyrev, 2018).

In October 2018, this problematic situation once again attracted the attention of the public in connection with the shooting of Alexei Krasovsky's film "Holiday", which is about the family of the Leningrad professor Voskresensky, who lives "in a special position" (i.e. quite nourishing and comfortable) in the conditions of the starving blockade of Leningrad. "The "patriotic" audience of the central mass media was once again insulted by such a topic and demanded that such a movie should not be allowed to go on in Russia. In this regard, the

\footnotetext{
${ }^{1}$ Peskov D. How to treat the comedy about the blockade of Leningrad // Access mode / https://vz.ru/society/2018/10/14/946011.html.
} 
director himself had to look for money to shoot the film and put it on the Internet on January 3, 2019.

The defenders of historical memory have overdone it this time. The film itself turned out to be, to put it mildly, very mediocre, not interesting and, at all, not scandalous. The number of its views on the Internet is minimal. I personally did not find in it any blasphemy or insults to the memory of the siege survivors. Yes, simple Leningrad siege-lodges and the party and official elite lived differently. Now it is difficult to surprise or cause some righteous anger among contemporaries. We got a lot of noise from the very idea of a different view on the blockade life...

But if we leave emotions aside, then from the point of view of modern social and practical philosophy the attitude to the events of the blockade of Leningrad can be different, and expressed in several aspects:

(1) Military and historical aspect — describes the chronicle of the blockade during the Great Patriotic War;

(2) Military and Heroic (patriotic) — gives a positive assessment of the courage and heroism of the siege survivors, based on traditional attitudes of "victory at all costs" and "victory will write everything down";

(3) Ethical-humanistic aspect - suggests questions about the expediency of large losses among the peaceful population of the besieged Leningrad from the point of view of modern humanism, mercy and priority of human rights (Höffe, 2015; Inglehart \& Welzel, 2005).

We are accustomed to considering the blockade in the first and second aspects, in the context of the principle of "victory at all costs", and this has hit the historical memory of the older generations of Russians, but the third aspect - the ethical-humanistic — is just beginning to manifest itself, and is being formed in the Russian public consciousness, which is gradually freed from totalitarian dogmas and power-centrism. Why can't we discuss the price of victory? Or about the "noble life" of some important persons during the blockade? After all, these questions are important for our modern and future life in order to formulate our modern principles, assessments and draw practical conclusions. Moreover, the very principle of "victory at any cost" is not absolute and not universal, and even outdated.

At the same time, it should be taken into account that some war veterans and some high-ranking officials of today's Russia may not like the new principles and practical conclusions. But again, this is their private opinion, and that's all. And for many other citizens, these conclusions can be very important. In addition, the opinion of individual officials and the journalists and ideologists who serve them are not absolute truths that are not subject to scientific and critical analysis. Thank God that we have moved away from the principle of "partisanship of truth" and have a reasonable right to question any public statements.

\section{Conclusion}

From the point of view of modern socio-practical philosophy, the initial thesis of our reasoning "the future must obey the past" is not a self-evident and unreliable statement, because there is no past or future in the present in which we live, and it is in the present (i.e. here and now) that we ourselves interpret the past and answer questions about our future. Anyone can take advantage of this opportunity to talk about the past and the future, but not everyone wants to do it. It should be taken into account that many people want to follow traditions and feel like joint heirs of the common past and some common future. This is quite natural, because it was easier to survive for centuries. But there are other people who now want to explain the past in their own way and plan the future in their own way. Their number gradually grows with the growth of independence and degrees of freedom of modern man (Myasnikov, 2017).

Rational-critical analysis should also take into account the interest of authoritarian power connected with 
programming the future by means of biogenetic interpretation of the historical past. However, such a rigid ideological determinism does not correspond to the complexity and nonlinearity of historical development, and recalls the recent denial of genetics as a science that contradicted the dogmas of official Marxism-Leninism.

The right of the mind to its own interpretation of the past and the design of the future gives a man the opportunity to calmly and honestly assert his will, to build his life on the measures of his happiness. And the more happy people in our society are, the better it will be for everyone.

\section{References}

Auzan, A. A. (2010). National values and modernization. Moscow: OGI. Polit. ru. (in Russian)

Höffe, O. (2015). Kritik der Freiheit: Das Grundproblem der Moderne. München: C.H. Beck Verlag.

Inglehart, R., \& Welzel, K. (2005). Modernization, cultural change and democracy: Consistency of human development. New York: Cambridge University Press.

Kozyrev, G. I. (2018). Image of the external enemy as a factor of legitimization of the political regime in modern Russia. Sotsiologicheskie Issledovaniya [Sociological Studies], 1, 52-58. (In Russian). DOI: 10.7868/S0132162518010063

Myasnikov, A. G. (2017). The right to lie as a trap for freedom. Polis. Political Researches, 5, 174-186. (In Russian). DOI: 10.17976/jpps/2017.05.12

Nikonov, V. A. (2015). The modern world and its origins. Moscow: Publishing house of Moscow (in Russian).

Russia in Search of Ideologies: Transformation of Value Regulators of Modern Societies. (2016). V. Martyanov \& L. Fishman, (Eds.). Moscow: Political Encyclopedia (in Russian). 